\title{
A Comparison of Professional Development Practices in Rural and Urban High Schools
}

\author{
Teresa Wallace \\ Eastern Kentucky University
}

\begin{abstract}
Because standards-based reform emphasizes improved teaching as the best path to increased learning and improved student performance, one would expect high performing schools to be implementing effective professional development practices. This study examines professional development practices in high performing urban and persistently low achieving rural high schools in Kentucky. Findings from the non-experimental descriptive study suggest similarities in professional development practices between the two groups. Differences existed in how well leadership addresses teacher professional development needs and in sufficient training to utilize instructional technology. Characteristics of effective professional development are not being fully implemented in either group of schools.
\end{abstract}

Key Words: professional development; characteristics of effective professional development; differentiated training opportunities

The 'Highly Qualified Teacher' requirement of the 2001 No Child Left Behind Act has put significant pressure on school districts to staff every classroom with a highly qualified teacher. Standards-based reform identifies improved teaching and professional development as key to educational reform (Fishman, Marx, Best, \& Tal, 2003). Leo and Coggshall (2013) contend high quality professional development is essential for teachers to understand and integrate the types of instruction demanded by the Common Core State Standards.

In Kentucky, four in ten public school students attend a rural school, the seventh highest rate in the U.S. (When Rural Matters, 2009). From 2010 to 2012, twenty-two public school districts in Kentucky contained schools identified as persistently low achieving (Priority Schools by Cohort, 2013). Fifteen of these twenty-two districts are rural (RLISP Eligibility Spreadsheet, 2013). Why Rural Matters 2009 reported educational outcomes of rural Kentucky students to be among the lowest in the U.S. As targeted professional development can lead to improved instruction and improved instruction may result in increased student achievement, it seems logical to explore professional development practices in schools with different educational outcomes.

The research question guiding this study was: Do professional development practices differ between high performing urban and persistently low achieving rural high schools in Kentucky?

\section{Theoretical Framework}

The primary goal of all professional development is to improve student achievement (Yoon, Garet, \& Jacobson, 2007). Extensive research has been conducted in an attempt to identify effective professional development for teachers (for example, Desimone, 2011; Fields, Levy, Karelitz, MartinezGudapakkam, \& Jablonski, 2012; Guskey \&Yoon, 2009). Many of these studies include characteristics of effective professional development identified by Sparks and Loucks-Horsley (1989) over two decades ago. In a 1989 meta-analysis of research and relevant literature, Sparks and Loucks-Horsley identified five characteristics of effective professional development:

1. Activities are conducted in school settings and linked to other school-wide improvement efforts.

2. Teachers are actively involved in planning, setting goals, and selecting activities.

3. Self-instruction is emphasized and a variety of "differentiated training opportunities" are offered.

4. Ongoing support and resources are provided.

5. Training is concrete and includes ongoing feedback, supervised trials, and assistance on request.

These characteristics of effective professional development are still relevant today. The National Institute for School Leadership (NISL, 2013) lists these characteristics, along with focus on learning for all, alignment with local and state standards, and best practices for effective professional development. 


\section{Methods}

This study used survey research. Data were gathered using an online survey instrument developed by the investigator specifically for this study. The survey was developed around the five characteristics of effective professional development identified by Sparks and Loucks-Horsley (1989). The survey consisted of 31 items using a 5-point Likert scale for responses. Administrators from four high performing high schools (on target to reach 100\% Proficiency on state assessments by 2014 and that had made Adequate Yearly Progress for the past three consecutive years) and four persistently low achieving high schools (scored in the lowest 5\% of high schools on state assessments in 2010 and did not make Adequate Yearly Progress for the past three consecutive years) in Kentucky were invited to participate in the study. Administrators from two high performing urban and three persistently low achieving rural high schools chose to participate. Survey links, instructions, and a deadline for responses were emailed by the investigator to principals of each participating school. The principals forwarded the email to all certified teachers in the building; 86 high performing and 99 persistently low achieving. Seventy-one teachers $(83 \%)$ from the two high performing high schools and seventy-two teachers $(73 \%)$ from the three persistently low achieving high schools completed the survey in March and April of 2012. All respondents remained anonymous.

\section{Findings}

To answer the research question "Do professional development practices differ between high performing urban and persistently low achieving rural high schools in Kentucky?", teachers responded to questions, developed around the five characteristics of effective professional development identified by Sparks and Loucks-Horsley.

\section{Does the location of professional development activities and the extent to which they are linked to other school-wide improvement efforts differ between high performing urban and persistently low achieving rural schools?}

Teachers in both groups agreed with Sparks and Loucks-Horsley (1989) that school level professional development was most effective, and teachers in both groups participated in school level professional development most frequently (Table 1).

Table 1

Educator Perception of Type vs. Received Professional Development

\begin{tabular}{lcccc}
\hline & \multicolumn{2}{c}{ High Performing } & \multicolumn{2}{c}{ Persistently Low Achieving } \\
\hline Location of Professional Development & $\begin{array}{c}\text { Percent Most } \\
\text { Effective }\end{array}$ & $\begin{array}{c}\text { Percent } \\
\text { Participation in } \\
\text { School }\end{array}$ & $\begin{array}{c}\text { Percent Most } \\
\text { Effective }\end{array}$ & $\begin{array}{c}\text { Percent } \\
\text { Participation in } \\
2012\end{array}$ \\
District & 57.7 & 47.9 & 63.9 & 59.7 \\
Regional Conference & 5.6 & 26.8 & 2.8 & 29.2 \\
State Conference & 18.3 & 14.1 & 4.2 & 6.9 \\
National Conference & 9.9 & 7.0 & 23.6 & 6.9 \\
\hline
\end{tabular}

Both groups thought district level professional development to be least effective, yet that was the second most frequent delivery method implemented in both high performing and persistently low achieving schools. Both groups indicated professional development was aligned to the school improvement plan, as shown in Table 2.

Table 2

Professional Development Aligned to School Improvement Plan

\begin{tabular}{|c|c|c|}
\hline $\begin{array}{l}\text { Professional Development Offerings in My School are Aligned to the } \\
\text { School Improvement Plan }\end{array}$ & High Performing & $\begin{array}{l}\text { Persistently Low } \\
\text { Achieving }\end{array}$ \\
\hline Strongly Disagree & $0 \%$ & $2.8 \%$ \\
\hline Disagree & $2.8 \%$ & $0 \%$ \\
\hline Agree & $83.1 \%$ & $62.5 \%$ \\
\hline Strongly Agree & $8.5 \%$ & $25.0 \%$ \\
\hline Don't Know & $5.6 \%$ & $9.7 \%$ \\
\hline
\end{tabular}


2. Does the level of teacher involvement in planning professional development differ between high performing urban and persistently low achieving rural schools?

A large number of teachers in both groups reported having a small or no role in planning professional development (Figures 1 and 2). In high performing schools, $40.2 \%$ of teachers said they played a small or no role in planning professional development. In persistently low achieving schools, $59.7 \%$ of teachers reported playing a small or no role in the planning of professional development.

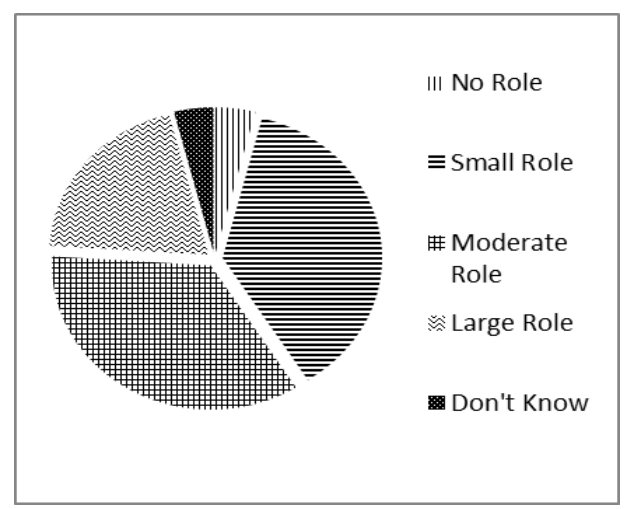

Figure 1. Roles played by teachers in high performing schools.

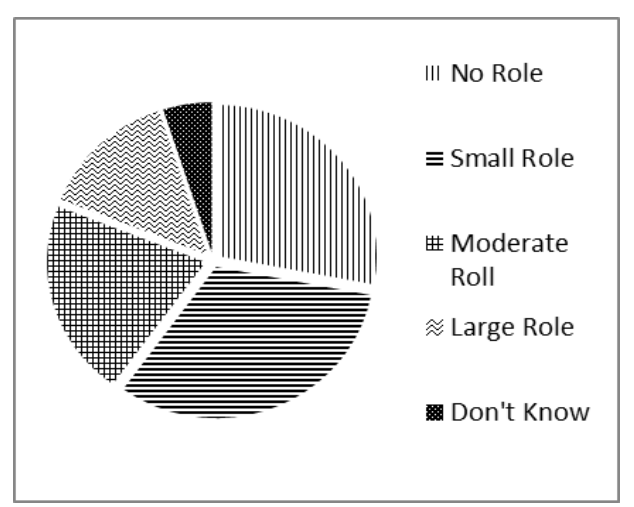

3. Does the level of differentiation of professional development differ between high performing urban and persistently low achieving rural schools?

Less than $50 \%$ of teachers in either group reported professional development is differentiated to meet individual teacher needs based on content and pedagogy. Only $40.3 \%$ of teachers in high performing schools and $38.0 \%$ in persistently low achieving schools indicated professional development was differentiated to meet their needs. There was a substantial difference between the percentage of teachers in the two groups reporting they had sufficient training to utilize instructional technology to improve student achievement. While $83.1 \%$ of teachers in high performing schools indicate they have had sufficient training to utilize instructional technology, only $48.6 \%$ of those in persistently low achieving schools report having had sufficient training.

4. Does the level of support and resources provided for professional development differ between high performing urban and persistently low achieving rural schools?

Both groups reported high levels of support from leadership, with $76 \%$ of teachers in high performing schools and $79.2 \%$ in persistently low achieving schools indicating leadership gives sufficient support to teachers. More teachers in high performing schools indicated leadership makes a sustained effort to address teacher professional development needs than those in persistently low achieving schools, as reflected in Table 3. The majority of teachers in high performing schools $(76.4 \%)$ and teachers in persistently low achieving schools (69.9\%).reported having sufficient professional development resources.

Figure 2. Roles played by teachers in persistently low performing schools.

Table 3

Leadership Addresses Professional Development Needs

\begin{tabular}{lcc}
\hline $\begin{array}{l}\text { School Leadership Makes a Sustained Effort to Address Teacher } \\
\text { Professional Development Concerns }\end{array}$ & High Performing & $\begin{array}{c}\text { Persistently Low } \\
\text { Achieving }\end{array}$ \\
\hline Strongly Disagree & $1.4 \%$ & $8.3 \%$ \\
Disagree & $16.9 \%$ & $23.6 \%$ \\
Agree & $56.3 \%$ & $51.4 \%$ \\
Strongly Agree & $18.3 \%$ & $12.5 \%$ \\
Don't Know & $7.0 \%$ & $4.2 \%$ \\
\hline
\end{tabular}




\section{Does the level of feedback and follow-up to professional development differ between high performing urban and persistently low achieving rural schools?}

There was little difference in the amount of followup to professional development received by the two groups. Fifty-nine percent of teachers in high performing schools and $55.5 \%$ of teachers in persistently low achieving schools reported adequate follow-up to professional development.

As shown in Table 4, less than $50 \%$ of teachers in either group reported professional development sessions were evaluated and results communicated to teachers.

Table 4

Evaluation of Professional Development

\begin{tabular}{|c|c|c|}
\hline $\begin{array}{c}\text { Professional Development is Evaluated and Results Communicated to } \\
\text { the Teachers }\end{array}$ & High Performing & $\begin{array}{l}\text { Persistently Low } \\
\text { Achieving }\end{array}$ \\
\hline Strongly Disagree & $4.2 \%$ & $5.6 \%$ \\
\hline Disagree & $53.5 \%$ & $43.1 \%$ \\
\hline Agree & $29.6 \%$ & $38.9 \%$ \\
\hline Strongly Agree & $4.2 \%$ & $8.3 \%$ \\
\hline Don't Know & $8.5 \%$ & $4.2 \%$ \\
\hline
\end{tabular}

Teachers' responses to the five questions indicated more similarities than differences in professional development practices in high performing urban and persistently low achieving rural high schools in Kentucky. Areas that differed were how well leadership addresses teacher professional development needs and sufficient training to utilize instructional technology.

\section{Discussion}

Research questions for this study were developed around the five characteristics of effective professional development identified by Sparks and Loucks-Horsley (1989) to determine how professional development practices in high performing urban high schools in Kentucky differ from those in persistently low achieving rural high schools in Kentucky. One would expect professional development in high performing schools to meet the characteristics of effective professional development, with a lower expectation for effective professional development in low performing schools. Sparks and Loucks-Horsley (1989) state professional development activities should be conducted in school settings and be linked to other school-wide improvement efforts. Results show this occurred in both high performing urban and persistently low achieving rural schools in this study.

According to Sparks and Loucks-Horsley (1989), teachers should be actively involved in planning professional development activities. One would expect this to be true in high performing schools, yet only $54.1 \%$ of teachers in high performing schools and $34.1 \%$ in persistently low achieving schools said they played a modest to large role in planning professional development. In the persistently low achieving rural schools, this finding could be a result of district initiated and planned professional development as part of the improvement efforts.

One would expect professional development in the high performing schools to be differentiated to meet individual teacher needs, as Sparks and LoucksHorsley (1989) identify as best practice. However, more than $50 \%$ of teachers in both groups reported professional development is not differentiated to meet their needs. Again, this finding could be a result of district initiated and planned professional development in both groups. This is a concern for rural districts as Why Rural Matters 2009 reports rural Kentucky schools to have high rates of poverty and students qualifying for special education, which would warrant differentiated professional development for those teachers. Of a bigger surprise was the substantial difference between the percentage of teachers in the two groupsthat had adequate training to utilize technology in the classroom to improve student achievement. Only $48.6 \%$ of teachers in the persistently low achieving schools reported having sufficient training to utilize technology, while $83.1 \%$ in high performing schools reported sufficient training. This could be a reflection of a lack of leadership emphasis on the use of technology in the persistently low achieving rural schools or a lack of access. Funding for technology could be an issue as all three persistently low achieving schools have a high percentage $(43 \%-74.1 \%)$ of students receiving free and reduced meals, while less than $20 \%$ of students in the high performing schools received free and reduced meals.

Sparks and Loucks-Horsley (1989) emphasize the importance of ongoing support and resources for professional development. Both groups reported high 
levels of support from leadership and less than $25 \%$ in either group reported a lack of adequate resources.

To be effective, Sparks and Loucks-Horsley (1989) stated professional development should include feedback and follow up. Again, one would expect both of these characteristics to be evident in high performing schools. However, less than $50 \%$ of teachers in either group reported professional development sessions were evaluated and results shared with teachers. Just over half the teachers in both groups reported adequate follow-up to the sessions. This could be a result of the professional development coordinators in the districts not knowing this is a characteristic of highly effective professional development or not having the time to monitor feedback and follow up. One way to address this would be to educate a teacher leader or facilitator in each building on the characteristics of effective professional development and then appoint this person to collect feedback and monitor follow up to professional development sessions.

\section{Limitations and Future Research}

Due to the limited number of participants in this study, there is a need to expand the research to include more teachers from high performing urban and persistently low achieving rural schools in the survey by including more schools in each category. There is also a need to probe further to determine the reasons the characteristics of effective professional development are not being implemented in these schools, especially in persistently low achieving rural schools.

Implications of the limited research, suggest a need for further investigation into the effect professional development has on student achievement, as conclusions cannot be drawn from the data here; and, professional development for teachers is a key mechanism for improving student achievement (Yoon, Duncan, Lee, Scarloss, \& Shapley, 2007).

In 2010-2011, over half of all operating public school districts in the U.S. were located in rural areas. Only $35 \%$ of fourth graders and $33 \%$ of eighth graders in rural schools scored proficient in reading on the NAEP, with $42 \%$ of fourth graders and $35 \%$ of eight graders scoring proficient in math on the NAEP (nces.ed.gov/programs/coe/indicator_tla.asp). Because research suggests that both teachers' content knowledge and pedagogy are significantly correlated with student learning (Hill, Rowan \& Ball, 2005), there is an urgency to complete further research on teacher professional development practices in rural schools.

\section{Implications}

Based on the results of this study, the following recommendations are offered to rural districts:

1. Districts and schools should establish professional development planning committees to actively involve teachers in planning their professional development activities. These committees should take into consideration both academic and nonacademic data of their school population when planning activities. One school may need to focus on reading for English Language Learners while another may need to focus on motivation of specific groups such as free and reduced lunch students.

2. Districts and schools should ensure professional development is differentiated to meet individual teacher needs. An emphasis should be placed on both content knowledge and pedagogy. Districts and schools should move away from a "one size fits all" method of professional development where all teachers in the building participate in the same training. Teachers should help identify individual training needs.

3. Based on information from Athans and Devine (2013), the use of technology such as computers, Smart Boards, blogs, slideshow software, and document cameras excites and motivates most students. Therefore, districts and schools should consolidate local, state and federal resources to better support the use of technology in rural schools. They should ensure teachers have adequate training on use of instructional technology in the classroom.

4. Districts and schools should develop formal methods for teachers to evaluate professional development activities to ensure teacher needs are being met. They should designate someone to monitor and ensure adequate follow up is being provided and teachers are not left to implement the training on their own.

While professional development practices alone are not keeping students in rural schools from reaching $100 \%$ proficiency, a change in professional development practices could go a long way in improving student achievement. Before schools can get our students to proficiency, teachers must be proficient in their content knowledge and pedagogy. 


\section{References}

Athans, S. \& Devine, D. (2013). Motivating every student in literacy: Including the highly unmotivated. New York, NY: Routledge

Desimone, L. (2011). Research \& Development: A primer on effective professional development. Phi Delta Kappan, 92(6), 68-71.

Fields,E., Levy, A., Tzur, K. Martinez-Gudapakkam, A., \& Jablonski, E. (2012). The science of professional development: If you offer it, will they come? If they come, will it matter? Phi Delta Kappan, 93(8), 44-46.

Fishman, B., Marx, R., Best, S., \& Tal, R. (2003). Linking teacher and student learning to improve professional development in systemic reform. Teaching and Teacher Education, 19(6), 643-658.

Guskey, T. \& Yoon, K. (2009). What works in professional development. Phi Delta Kappan, 90(7), 495-499.

National Institute for School Leadership Instructor's Guide, Course Two. (2013). Washington, DC: A Subsidiary of the National Center on Education and the Economy.

Priority Schools by Cohort. (2013). Retrieved Hill, H., Rowan, B., \& Ball, D. L. (2005). Effects of teachers' mathematical knowledge for teaching on student achievement. American Educational Research Journal, 42(2), 371-406December 1, 2013, from
http://education.ky.gov/school/Documents/ Priority\%20Schools\%20by\%20Cohort\%20map071113.pdf.

RLISP Eligibility Spreadsheet for Fiscal Year 2013/School Year 2013/2014, Kentucky. (2013). Retrieved November 29, 2013, from www2.ed.gov/programs/reaprlisp/eligible13/index. html.

Sparks, D., \& Loucks-Horsley, S. (1989). Five models of staff development for teachers. Journal of Staff Development, 10(4), 40-57.

The Status of Rural Education. (2013). Retrieved December 1, 2013, from nces.ed.gov/programs/coe/indicator_tla.asp.

Yoon, K.S., Duncan, T., Lee, S., Scarloss, B., \& Shapley, K. (2007). Reviewing the evidence on how teacher professional development affects student achievement. Issues \& Answers, REL 2007-No. 033. Washington, DC: U.S. Department of Education, Institute of Educational Sciences.

Yoon, K.S., Garet, M., Birman, B., \& Jacobson, R. (2007). Examining the effects of mathematics and science professional development on teachers' instructional practice: Using professional development activity logs. Washington, DC: Council of Chief State School Officers.

\section{About the author:}

Teresa Wallace, Ed.D. retired from P-12 public education before joining the faculty of the Educational Leadership and Policy Studies department at Eastern Kentucky University in 2011. Research interests include various areas in P-12 education and women's studies. 